\title{
Sivistyksen kunnianpalautus
}

Maria Joutsenvirta \& Arto O. Salonen (2020). Sivistys vaurautena. Radikaalisti, mutta lempeästi kohti kestävää yhteiskuntaa. Basam Books. 363 sivua.

VÄITETÄÄN ETTÄ postmodernissa maailmassa ei ole suuria kertomuksia, tai ne ovat ainakin merkittävästi heikentyneet. Sivistys vaurautena on väitteestä eri mieltä; sen kunnianhimoisena päämääränä on luoda vahva ja vaikuttava suuri narratiivi, jonka edistyskertomuksena ovat vaurauden aineettomat hyödykkeet. Samalla haastetaan mekanistinen ja materialistinen maailmankuva, joka perustuu jatkuvaan aineelliseen talouskasvuun ja välineelliseen ihmiskuvaan.

Käsillä on ensimmäinen kokonaisvaltainen suomenkielinen teos, jossa sivistyksen suurempi tarina kerrotaan poikkitieteellisesti ja laajemmin ekososiaalisessa yhteydessään, kokka kohti kestävää tulevaisuutta.

Akateemisia julkaisuja ja artikkeleita on toki julkaistu viljalti viime vuosina, ja toinen kirjoittajista, Arto O. Salonen on tuonut ekososiaalisen sivistyksen käsitteen Suomeen. Teos on samalla jatkoa Joutsenvirran ja Salosen Aikuiskasvatuksen vuoden tiedeartikkelina palkitulle artikkelille "Vauraus ja sivistys yltäkylläisyyden ajan jälkeen" (Aikuiskasvatus 2/2018).

Dosentti Ari Jaaksin valokuvat antavat tarvittavia hengähdystaukoja, pysähtymisen hetkiä tekstien vuolaassa virrassa.

\section{AVARTUMISEN JA YLEVYYDEN YLISTYS}

Kirjan julkistamistilaisuudessa toukokuussa 2020 Salonen tähdensi, että meidän ei pidä karttaa yleviä sanoja, koska ne nostavat ihmismieltä katsomaan elämää ja tulevaisuutta merkityksellisten sisältöjen kautta. Kun Suomessa oli valmiuslaki, ja brutaali koronapandemia piinasi koko ihmiskuntaa, kontrasti oli melkoinen. Se herkisti miettimään sivistyksen olemusta ja sivistymisen prosessia.

"Sivistyminen on omasta ainutlaatuisuudesta tietoiseksi tulemista, sen jatkuvaa ylittämistä ja käyttämistä hyvyyden, totuuden ja kauneuden lisäämiseksi yhteisöissä, yhteiskunnassa ja maailmassa, jotta hyvän tulevaisuuden toivo vahvistuisi", Salonen totesi julkistamistilaisuudessa.

Joutsenvirta puolestaan nosti esille koronakriisin repeämän, jossa hallinnan illuusio särkyi, mutta samalla avautui auttamisen, inhimillisyyden ja planetaarisen vastuun mahdollisuudet.

Hän kutsui koronaa kairos-hetkeksi, jossa "[--] tapahtuu jotain merkityksellistä, joka kyseenalaistaa normaalin, kronologisen ja ulkoisen, etenemisen ja voi muuttaa kaiken".

Teos on kirjoitettu aforistiseen tyyliin, dialogisesti ja sykli-
MARIA JOUTSENVIRTA

\& ARTO O. SALONEN

SIVISTYS VAURAUTENA

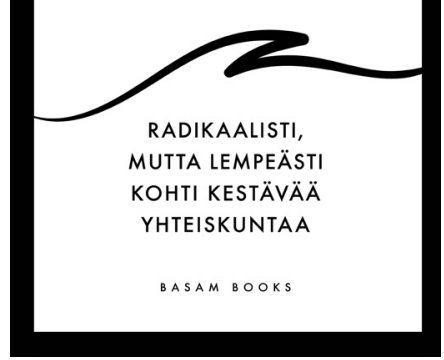

sesti teemoittain. Osittain se jäsentyy myös kronologisesti, mitä ei kokonaan voi välttää, onhan teos edistyskertomus. Kronologisuus näkyy esimerkiksi kirjan taulukoissa, joissa eritellään vanha edistysihanne eli valistus ja uusi edistyskertomus, sivistyminen, sekä materiaaliset arvot, kuten elintaso, ja jälkimateriaaliset arvot, kuten elämänlaatu. Syklisyys näkyy taulukossa, jossa kuvataan planetaarista sivistystä avartumisena, alkaen minäkeskeisyydestä ja jatkaen ihmis- ja elämänkeskeisyyden kautta ekosysteemikeskeisyydeksi, jossa "planetaarisesti sivistynyt ihminen tiedostaa, että ihmisen elämä on täysin riippuvaista elinvoimaisesta luonnosta”.

\section{SIVISTYKSEN JA VAURAUDEN} SUHDE

Teoksen otsikko velvoittaa. Mikä siis on sivistyksen ja vaurauden suhde, ja miten tämä näkyy ihmisten ajattelussa ja arjessa niin 


\section{VALISTUKSEN JATKUVAN}

TALOUSKASVUN KESKIÖSSÄ ON RAHA. että postmaterialistinen siirtymä saavutetaan eri planetaaristen aikapommien aikana? Kysymys on velvoittava, koska ylevien sanojen takana pitää olla jotain sisältöä, olkoonkin aineetonta.

Valistuksen jatkuvan talouskasvun keskiössä on raha, jolla mitataan bruttokansantuotteen ohella lähes kaikkea: omaisuutta, kulutusta, jopa ihmisarvoa. Kirjan yhtenä juonteena on haastaa suppea, materialistinen tulkinta vauraudesta tuomalla näkyviin jälkimaterialistinen, aiempaa moninaisempi käsitys, jossa on tilaa sosiaaliselle vaurastumiselle, kairos-tyyppiselle ajalliselle vauraudelle, sekä yhteisvauraudelle. Esimerkkeinä yhteisvauraudesta mainitaan kirjastot, ekosysteemien ja ihmisverkostojen vuorovaikutukset. Näiden arvoa ei voi eikä pidä mitata euroissa.

Uuden edistyskertomuksen sivistysyhteiskunnassa raha on hyvä renki mutta huono isäntä. Vanhan ja uuden edistyskertomuksen välisiä muutosvoimia kuvattaessa juuri sivistyminen nähdään ydinroolissa, siirtymänä materiaalisesta monimuotoiseen vaurauden käsitykseen. Kirjoittajien mukaan muutokseen tarvitaan kapean osaamiskeskeisen suorittamisen sijaan laajempaa yhteisluomista (co-creation) "[--] jossa kuvitellaan uusia näky- miä ja luodaan uutta” esimerkiksi kehollisuuden ja taiteen kuvittelukyvyn keinoin.

Kouluissa ja oppilaitoksissa siirtymä toteutuu yhteiskuntaa uudistavalla oppimisella. Sen avulla oppilaitokset siirtyvät toisintavasta kilpailuhenkisyydestä ennakoivaan tuotanto- ja palveluorganisaatioon, josta siirrytään uudistavaan systeemitason muutososaamiseen. Samalla siirtymä mahdollistaa oppijoiden muutoskykyä itseohjautuvuudesta yhteisohjautuvuuteen. Kestävän kehityksen OKKA-säätiön kanssa tehtävät koulutushankkeet ovat osa siirtymää, ja koen esimerkiksi vapaan sivistystyön parissa toimivat koulutushankkeet olevan muutoksentekijän roolissa 2020-luvun alun sivistyspedagogiikan paradigman muutoksessa.

\section{SIVISTYS SULAUTUU}

Mikä on koulutuksen ja sivistyksen välinen suhde? Vastaukseni on: koulutus kasautuu, sivistys sulautuu. Erilaisuus ei ole tiukasti dikotominen vaan lempeästi ja radikaalisti vuorovaikutteinen. Sivistys vaurautena -teoksessa sivistys haastaa koulutusajattelua, joka perustuu ainaiseen suorittamiseen, kilpailemiseen ja erikoistuvaan osaamiseen. Siten teos on avartumiseen ja arvokkuuteen perustu- van sivistyksen kunnianpalautus. Sillä on kantokykyä kestävän tulevaisuuden luomiskertomuksessa, jossa huominen ja luominen sulautuvat yhteen.

\section{BJÖRN WALLÉN}

VM, puheenjohtaja, organisaatiokonsultti, fasilitaattori

Vapaa Sivistystyö ry, Sivistystyön Vapaus ja Vastuu (SVV) -ohjausryhmä 